\title{
Students' Perception on the Use of Multimedia in Learning among Selected Schools in Misamis Oriental, Philippines
}

\author{
Helen V. Idnay \\ Department of Languages and Social Sciences \\ Mindanao State University at Naawan \\ Integrated Developmental School \\ NaawanMisamis Oriental \\ Philippines
}

\begin{abstract}
Nowadays there are an enormous new media technologies being used to create the complete multimedia experience. For instance, virtual reality integrates the sense of touch with video and audio media to immerse an individual into a virtual world..This study was conducted to determine the students' perception on the use of multimedia in terms of availability of and access, equipment and software, knowledge and skills and administrative support for the multimedia facilities, and compare the students' perception on the use of multimedia by year level and by type of school. Thestudy attempted to find out the significant differences on the perceptions of the respondents in using multimedia by year level and type of school, Findings revealed that students gave higher percentage in the use of computer and internet. Students coming from private institutions have higher accessibility using the technology compared to students from State Universities. There were no significant differences in both schools in terms of administrative support. However, the type of school had influenced their perceptions about the knowledge and skills with higher values from private institutions. .From the results obtained, good insights and inputs are drawn to help administrators in the policy formulations about multimedia on Technology Education. Students perceived that bigger multimedia laboratories be installed especially in government universities. There must be in-service trainings and seminars for teachers and students. For teachers, younger generations had more chance using the technology. Administrators should therefore make plans on how the issues of multimedia be addressed properly, effectively and efficiently.
\end{abstract}

Keywords: Multimedia, profile, technology policy, perception, knowledge, availability, skills, administrative support

\section{Introduction}

The vision of a classroom as a community of learners challenges the traditional views of teaching, learning, and questioning. In the course of time and with the recent technological developments, studies reveal that teaching can be viewed as a social activity (Mathis and Clark (1993) that invites students to interact with their teacher and peers as they engage with the content. Further, an opportunity has emerged to introduce more efficient instruction which is made possible as the teachers and students recognized the role of multimedia as a tool and as a core function of both learning and teaching in the classroom (Hill and Novelli, 1994). Accordingly, this has paved the way in which teaching and learning processes can be fascinating and intellectually- stimulating, more experiential, inductive, hands-on learning, more emphasis on higher order thinking, and more responsibility transferred to students for their work. As commonly defined, multimedia is an instructional technique to a traditional instructional method. It comes in many different forms such as the television, graphics, computer-delivered combination of text, pictures, audio and video, commonly found on resources such as the World Wide Web and CD ROMs (Jackson, 2002). While a lecture can be extremely informative, integrating pictures or video images can help an individual learn and retain information much more effectively.

In addition, as computers increase their power(Fletcher, 1991), new ways of integrating media will make the multimedia experience extremely intricate and exciting. Several statistics from different sources show the effectiveness of multimedia in education and that, its applications can truly enhance student learning. However, despite the overwhelming positive contributions to learning the multimedia technology can offer, its use may somehow disrupt the learning process seriously unless everyone realizes that the main focus and objective (National Science Foundation ,1996)is to be on learning with technology and not about the technology. For this and many other reasons, it is helpful to have a clear understanding if the multimedia has really made a difference in the teaching-learning processes. Studies revealed by Slack (1999) stated that the infrastructure of a multimedia-enabled classroom is complex and implies many radical changes in all areas including curriculum development, pedagogical approach, faculty training, and organizational matters. 
Knowing that most schools in the Philippines, are into a multimedia-assisted classroom instruction as a tool to reach a variety of learners, whether a student is hands-on, visual, auditory, or social learner, this study was conceptualized to determine how the respondents' profile, including their educational background, skills and extent of utilizing the multimedia technology are related to their perceptions about the status of the use of multimedia in terms of availability, knowledge and administrative support to acquire the technology devices for classroom instruction. This chapter presents the locale of the study, the respondents, design, research instrument and its administration, and the ethical considerations involved in data gathering.

\section{Methodology}

There were 198 education students from the college of education of Xavier University (XU)), Liceo de Cagayan University (LDCU), and Mindanao University of Science and Technology (MUST), and one (1) in Naawan, Misamis Oriental, the Mindanao State University- Naawan (MSU-N) as respondents of the study.This paper utilized the surveyquestionnaire method. The study used the descriptive approach to generate primary data from the respondents. This study employed the stratified random sampling, Self-constructed close-ended questions formed part of the questionnaire were used as a research tool. These questionnaires contained items that allowed the respondents to provide their profile and their perceptions on the use of multimedia facilities in the classroom. When survey was over, the completed questionnaires were collected, and were prepared for data processing and statistical treatment. Prior to data collection, the proponents were ensured that an informed consent was obtained. The respondents were given an assurance that any information revealed in the survey and data collection process will be respected and will be kept highly confidential as part of ethics in research. Also the research procedures were carried out in a way that it will not cause any physical, psychological or emotional harm on the part of the respondents.

\section{Results and Discussion}

Table 1 shows the frequency analysis and percentage values about the students' perceptions on the availability and access to facilities, equipment and software. The data had shown that $82.8 \%$ of them were in strong agreement that experienced multimedia personnel are available for assistance. Similarly, $79.8 \%$ of them also agreed that there's appropriate multimedia software available for the students, while $77.3 \%$ stated that there is adequate equipment for multimedia use is indeed adequate to support the number of students needing it. However, students believed that there is a need to increase the number of technical laboratory for big-sized classes averaging from 40 to 60 students per class which is true to public schools. On the average, frequency analysis had shown that majority of the students perceived that multimedia facilities, equipment and software are available and accessible in their respective institutions.

Table 1. Students' perception on the availability of and access to facilities, equipment, and software

Items
Agree/Strongly

Agree

f $\%$
Disagree/Strongly Mean
Disagree
f $\%$

1. The multimedia devices are available

132

66.7

66

33.3

2.75

anytime these are needed

2. Accessibility of software and website

145

73.2

53

26.8

2.82

is sufficient

3. There is an increased number

of tech labs for big-sized classes

4. There is adequate equipment for multimedia use

110

55.5

88

88

2.61

153

77.3

45

22.7

2.84

5. There is appropriate multimedia software available

150

79.8

40

20.2

2.88

6. Experienced multimedia personnel

164

82.8

34

17.2

2.94 
Overall mean: $\quad 2.81$

Standard Deviation: 0.45

Table 2 displays the students' perception on the knowledge and skills in using multimedia. Most (90.9\%) of the students supported the idea which states that the tool bars on the computer screen make things easy for them to do lay outing in relation to their report. Similarly, that $90.4 \%$ of the students strongly agreed when asked if they do use multimedia devices for learning activities especially during class reporting. Additionally, $86.9 \%$ found it easy for them to create designs that are useful in paper presentations. Finally, 168 of them were in agreement that multimedia devices were easy to navigate.

Table 2. Students' perception on their knowledge and skills in using multimedia

\begin{tabular}{|c|c|c|c|c|c|}
\hline \multirow[t]{2}{*}{ Items } & \multicolumn{2}{|c|}{$\begin{array}{l}\text { Agree/Strongly } \\
\text { Agree }\end{array}$} & \multicolumn{2}{|c|}{$\begin{array}{c}\text { Disagree/Strongly } \\
\text { Disagree }\end{array}$} & \multirow[t]{2}{*}{ Mean } \\
\hline & $\mathrm{f}$ & $\%$ & $\mathrm{f}$ & $\%$ & \\
\hline $\begin{array}{l}\text { 1.You find multimedia } \\
\text { devices easy to navigate }\end{array}$ & 168 & 84.8 & 30 & 15.2 & 3.06 \\
\hline $\begin{array}{l}\text { 2. Students use multimedia } \\
\text { devices for learning } \\
\text { activities such as class } \\
\text { reporting }\end{array}$ & 179 & 90.4 & 19 & 9.6 & 3.18 \\
\hline $\begin{array}{l}\text { 3. I do not have sufficient } \\
\text { skills to use multimedia. }\end{array}$ & 135 & 68.2 & 63 & 31.8 & 2.88 \\
\hline $\begin{array}{l}\text { 4.The tool bars on the } \\
\text { computer screen make } \\
\text { things easy for me to do } \\
\text { lay outing of my report }\end{array}$ & 180 & 90.9 & 18 & 9.1 & 3.14 \\
\hline $\begin{array}{l}\text { 5.I can easily create } \\
\text { designs that are useful } \\
\text { in paper presentations }\end{array}$ & 172 & 86.9 & 26 & 13.1 & 3.07 \\
\hline
\end{tabular}

\begin{tabular}{llll}
\hline Overall mean: & 3.06 & Standard Deviation: & 0.44
\end{tabular}

Based on frequency analysis shown in Table 3, majority of the students (90.4\%) perceived that the administration is giving its support in curricular planning in relation to teaching the technology skills. They also perceived that the administration was where they tried figuring out how relevant the technology is, in imparting knowledge to students. About $71 \%$ of the students had a perception that there was a periodic inventory of multimedia done by the administration. This is important for them to have this periodic checking to figure out which among the multimedia facilities are still functional and which ones are not. This way, the information will serve as useful inputs for planning and would be a necessary yardstick in budget allocation, repairs and the like. 
Table 3. Students' Perceptions on administrative support for multimedia facilities

Items

1.Local and state in-service
or summer training students
are provided for free

2.Theincreased funding for computers and equipment is one concern the administrators had tried to discussed with the students

\section{The administration supports}

curriculum for teaching

technology skills

\section{The school administrators made classroom observations that use multimedia}

\section{Periodic inventory of multimedia devices \\ are conducted}

\author{
Agree/Strongly \\ Agree \\ f $\%$
}

$106 \quad 53.5$

$134 \quad 67.7$

179

90.4

19

9.6

3.03
Disagree/Strongly Mean

$\mathrm{f}$

$92 \quad 46.5$

2.52

$\begin{array}{lll}64 & 32.3 & 2.74\end{array}$

Overall mean:

2.78

Standard Deviation: $\quad 0.46$

Table 4 shows the t-values obtained when the students' perception on the access to and availability of multimedia facilities, equipment and software were compared by year level. Results revealed that although there were mean differences between the two groups where the third year students exhibited slightly higher values than the fourth year students, these differences were not significant enough to cause variations in their perceptions as evidenced by the mean t-values $(0.65)$ which did not reach the required value for significance. In other words, both groups of respondents have had the access to the multimedia facilities and that the experienced multimedia personnel were available for assistance.

Table 4. Comparative analysis of the perception of the students on the availability of and access to facilities, equipment, and software by year level $(n=198)$

\begin{tabular}{llllll}
\hline Items & Category & Mean & $\mathrm{t}$-value & p-value & Interpretation \\
\hline $\begin{array}{l}\text { 1. The multimedia devices } \\
\text { are available anytime } \\
\text { these are needed }\end{array}$ & $\begin{array}{l}\text { Third year } \\
\text { Fourth year }\end{array}$ & $\begin{array}{l}2.77 \\
2.73\end{array}$ & 0.31 & 0.760 & Not significant \\
$\begin{array}{l}\text { 2. There is a sufficient } \\
\begin{array}{l}\text { accessibility of software } \\
\text { and websites }\end{array}\end{array}$ & $\begin{array}{l}\text { Third Year } \\
\text { Fourth Year }\end{array}$ & 2.81 & -0.30 & 0.760 & Not significant \\
$\begin{array}{l}\text { 3.There is an increased } \\
\text { number of tech labs for }\end{array}$ & $\begin{array}{l}\text { Third Year } \\
\text { Fourth Year }\end{array}$ & 2.66 & 1.09 & 0.279 & Not significant
\end{tabular}

big-sized classes 
4.There is adequate equipment for multimedia use.

5. There is appropriate Third Year multimedia software Fourth Year 2.82 available

6. Experienced multimedia Third Yea personnel are available Fourth Year for assistance

7. Availability of and access Third Year to facilities, equipment, Fourth Year $\begin{array}{ll}\text { Third Year } & 2.84 \\ \text { Fourth Year } & 2.85\end{array}$

$\begin{array}{ll}\text { Third Year } & 2.84 \\ \text { Fourth Year } & 2.85\end{array}$

2.92

1.23

$-0.09$

0.931

Not significant

and software

$2.97 \quad 0.62 \quad 0.537 \quad$ Not significant

2.91

2.83

0.65

$0.514 \quad$ Not significant

In Table 5, shown is a comparative analysis of the values obtained from the two groups (year levels) of students regarding their perceptions to describe their knowledge and skills in using multimedia. Results show that the mean and tabulated values did not vary significantly at $5 \%$ probability level. This seemed to indicate that all groups had equally high Knowledge and skills in using multimedia.

Table 5. Comparative analysis of the perception of the students on the knowledge and skills in using multimedia by year level $(\mathrm{n}=198)$

\begin{tabular}{llllll}
\hline Items & Category & Mean & $\mathrm{t}$-value & p-value & Interpretation \\
\hline
\end{tabular}

1. You find multimedia devices easy to navigate

2. Students use multimedia devices for learning activities such as class reporting

3. I do not have sufficient skills to use multimedia.

4. The tool bars on the computer screen make things easy for me to do lay outing of my report

5. I can easily create designs that are useful in available
Third year $\quad 3.09$

Fourth Year 3.01

$\begin{array}{lll}0.90 & 0.367 \quad \text { Not significant }\end{array}$

Third Year $\quad 3.17$

$-0.29$

0.770

Not significant

Fourth Year 3.19

Third Year $\quad 2.80$

$-1.66$

0.098

Not significant

Fourth Year 2.99

Third Year

3.17

0.83

0.410

Not significant

Fourth Year 3.10

Third Year 3.06

$-0.36$

0.721

Not significant

As shown in Table 6, the third year students had higher level of perceptions that they were receiving support from the administration in terms of improving or upgrading multimedia facilities than the fourth year students. In particular, their perceptions differed significantly $(2.38$ and 2.0$)$ on one dimension where the school administrators made classroom observations to check whether or not multimedia is integrated in the instruction. 
Table 6. Comparative Analysis of the Perception of the Students on Administrative Support by Year Level (n=198)

Items Category

Mean $\mathrm{t}$-value

p-value

interpretation

1 Local and state inservice or summer training for students are provided for free

2.The increased funding for computers and equipment is one concern the administrators had tried to discuss with the students

\section{I The administration Supports}

curriculum for teaching technology skills

\section{The school administrators Made classroom observations that use multimedia \\ 5. I can easily create designs that are useful in available}

\section{Administrative support and above}

$\begin{array}{ll}\text { Third year } & 2.61 \\ \text { Fourth Year } & 2.39\end{array}$

$1.98 \quad 0.050 \quad$ Not significant

Third Year $\quad 2.79$

Fourth Year 2.67

$\begin{array}{lll}1.17 & 0.244 & \text { Not significant }\end{array}$

$\begin{array}{lllll}\text { Third Year } & 3.04 & 0.41 & 0.684 & \text { Not significant }\end{array}$

Fourth Year 3.01

Third Year $\quad 3.17$
Fourth Year

0.83

0.410 Not significant

Third Year 2.84

2.38

0.018 significant*

Fourth Year 2.63

Third Year 2.83

Fourth Year $\quad 2.70$
0.047 significant*

*significant at 5\% probability level

Moreover, the table (7) below presents the summary of values for comparing the perceptions of the students according to the type of school where they were enrolled in college.The calculated T-values had shown highly significant differences (-4.32 and -4.36) at 5\% and 1\% levels, indicating that those in private institutions had higher perceptions on the availability of and access to multimedia facilities when compared to those in state universities. Apparently, private academic institutions have more budget allocation for its facilities, and the said budget comes from tuition fees. Also, private schools have merely sole control of the funds, and that the administrators, being in a smaller entity (compared to government or state universities) could easily manage their financial resources. In contrast, due to the meager share of funds for education in the government's annual budget, it will take some time before the shortage of multimedia facilities and other instructional needs like 
Table 7. Comparative analysis of the perception of the students on the availability of and access to facilities, equipment, and software by type of school $(n=198)$

\begin{tabular}{|c|c|c|c|c|c|}
\hline Items & Category & Mean & $\mathrm{t}$-value & p-value & Interpretation \\
\hline $\begin{array}{l}\text { 1.The multimedia } \\
\text { devices are available } \\
\text { anytime you need it }\end{array}$ & $\begin{array}{l}\text { SUC } \\
\text { Private }\end{array}$ & $\begin{array}{l}2.63 \\
2.86\end{array}$ & -2.38 & 0.018 & Significant* \\
\hline $\begin{array}{l}\text { 2. There is a sufficient } \\
\text { accessibility of software }\end{array}$ & $\begin{array}{l}\text { SUC } \\
\text { Private }\end{array}$ & $\begin{array}{l}2.62 \\
3.00\end{array}$ & -4.14 & $<0.001$ & Very significant*** \\
\hline
\end{tabular}

and websites

concern the

3.I There is an increased

SUC

2.50

$-2.26$

$0.025 \quad$ Significant*

number of tech labs for

Private

2.72

big-sized classes

$\begin{array}{llllll}\text { 4.There is adequate } & \text { SUC } & 2.71 & 2.97 & 0.002 & \text { Very significant** } \\ \text { equipment for multimedia } & \text { private } & 2.97 & & & \end{array}$

use.

$\begin{array}{llllll}\text { 5. There is appropriate } & \text { SUC } & 2.80 & -2.06 & 0.041 & \text { Significant* } \\ \text { multimedia software } & \text { Private } & 2.95 & & & \\ \text { available } & & & & \end{array}$

$\begin{array}{llllll}\text { 6. Experienced } & \text { SUC } & 2.95 & -4.32 & <0.001 & \text { Very significant** } \\ \text { multimedia personnel } & \text { Private } & 2.76 & & & \\ \text { are available for } & & & & \\ \text { assistance } & & & & \end{array}$

$\begin{array}{lllll}\text { 7.Availability of and access } & \text { SUC } & 3.12 & -4.36 & <0.001 \text { Very significant** } \\ \text { to facilities, equipment, } & \text { Private } & 2.94 & & \end{array}$ and software

*significant at 5\% level $\quad * *$ significant at $1 \%$ level

Table 8 shows the mean differences between private and state universities in terms of their knowledge and skills in using multimedia. Comparative analysis reveals highly significant differences (mean T-value -5.71) at $1 \%$ level which indicated that students from private institutions had better exposure and experiences, thereby enhancing their skills related to multimedia technology. Obviously, private schools of any levelcan provide their students more facilities; in most cases, in a one to one ratio, thereby allowing each student to avail a clear hands- on experience, more time to focus and that they can learn faster than they are in groups, i.e., 1 computer to 10 students. 
Table 8. Comparative analysis of the perception of the students on the knowledge and skills in using multimedia by type of school $(n=198)$

Items

Category

Mea $\mathrm{t}$-value

p-value Interpretation

1.You find multimedia

SUC

devices easy to

Private

$3.25-4.81$

$<0.001$ Very significant**

navigate

2. Students use multimedia SUC devices for learning activitiesPrivate such as class reporting

$3.01<0.001 \quad$ Very significant**

3.I do not have sufficient

SUC

2.68

$-3.50$

0.001 Very significant**

skills to use multimedia

Private

3.06

4.The tool bars on the

SUC

3.00

$-3.56$

$<0.001$ Very significant**

computer screen make

private

3.27

things easy for me to do

lay outing of my report

$\begin{array}{llllll}\begin{array}{l}\text { 5. I can easily create } \\ \text { designs that are useful in }\end{array} & \begin{array}{l}\text { SUC } \\ \text { Private }\end{array} & 2.93 & -3.37 & 0.001 & \text { Very significant** }\end{array}$

paper presentations

\begin{tabular}{|c|c|c|c|c|c|}
\hline $\begin{array}{l}\text { 6. Experienced } \\
\text { multimedia personnel } \\
\text { are available for } \\
\text { assistance }\end{array}$ & $\begin{array}{l}\text { SUC } \\
\text { Private }\end{array}$ & $\begin{array}{l}2.95 \\
2.76\end{array}$ & -4.32 & $<0.001$ & Very significant** \\
\hline $\begin{array}{l}\text { 7.Knowledge and skills in } \\
\text { using multimedia }\end{array}$ & $\begin{array}{l}\text { SUC } \\
\text { Private }\end{array}$ & $\begin{array}{l}2.89 \\
322\end{array}$ & -5.71 & $<0.001$ & Very significant** \\
\hline
\end{tabular}

*significant at $1 \%$ level

In Table 9, it is very evident that both private and public institutions had similar perception on the presence of administrative support in their institution, exemplified by the recorded mean values and calculated t-values that did not vary significantly at $1 \%$ level. As shown in the table, the t-values are lower than the p-value. This should be construed that school heads from either public or private institutions have concerns to their constituents especially in terms of improving the quality of education..

Table 9. Comparative analysis of the perception of the students on administrative support by type of school (n=198)

\begin{tabular}{|c|c|c|c|c|c|}
\hline Items & Category & Mear & -value & p-value & Interpretation \\
\hline $\begin{array}{l}\text { 1.Local and state in- } \\
\text { service or summer } \\
\text { training students are } \\
\text { provided for free }\end{array}$ & $\begin{array}{l}\text { SUC } \\
\text { Private }\end{array}$ & $\begin{array}{l}2.55 \\
2.50\end{array}$ & 0.50 & 0.620 & Not Significant \\
\hline $\begin{array}{l}\text { 2. The increased funding } \\
\text { for computers and } \\
\text { equipment is one } \\
\text { concern the } \\
\text { administrators had tried } \\
\text { to discussed with the } \\
\text { students }\end{array}$ & $\begin{array}{l}\text { SUC } \\
\text { Private }\end{array}$ & $\begin{array}{l}2.76 \\
2.73\end{array}$ & 0.30 & 0.764 & Not significant \\
\hline
\end{tabular}




\begin{tabular}{|c|c|c|c|c|c|}
\hline $\begin{array}{l}\text { 3.The administration } \\
\text { Supports curriculum for } \\
\text { teaching technology } \\
\text { skills }\end{array}$ & $\begin{array}{l}\text { SUC } \\
\text { Private }\end{array}$ & $\begin{array}{l}2.95 \\
3.11\end{array}$ & -2.15 & 0.033 & Not significant \\
\hline \multicolumn{2}{|c|}{ 4.The school administratorsSUC } & 2.77 & -2.31 & 0.022 & Not significant \\
\hline $\begin{array}{l}\text { The school administrators } \\
\text { that use multimedia }\end{array}$ & Private & 2.96 & & & \\
\hline \multicolumn{2}{|c|}{ 5. The school administratorsSUC } & 2.70 & -1.40 & 0.163 & Not significant \\
\hline $\begin{array}{l}\text { made classroom } \\
\text { observations } \\
\text { that use multimedia }\end{array}$ & Private & 2.82 & & & \\
\hline \multirow[t]{2}{*}{ 6.Administrative support } & SUC & 2.74 & -1.29 & 0.199 & Not significant \\
\hline & Private & 2.82 & & & \\
\hline
\end{tabular}

\section{Recommendations}

From the findings obtained in the study, it is recommended that the same study be conducted involving students not only from the College of Education but also from other colleges. Similar study be done with more schools, including vocational and high schools; and the sample size needs to be determined based on the total population enrolled in a particular college and/or degree programs in order to generate information that would describe the whole picture of the issues being studied.The administration needs to find grants or sponsors to help in the funding for additional multimedia equipment and facilities in their respective schools.

\section{References}

Atkinson, R. (1968). Computerized instruction and the learning process. American Psychologist, 23, 225-239

Aydin, 2007

Banal III, Conrado. 2007. "Who's afraid of education hi-tech tools?"

http://business.inquirer.net/money/columns/view_article.php?article

Brett 1998. 'An intuitive, theoretical and empirical perspective on the effectiveness question for multimedia http://pers www.wlv.ac.uk/ le1969/index.htm

Diaz, 2007

Fletcher, J.D. (1991, Spring). Effectiveness and cost of interactive videodisc instruction in defense training and education. Multimedia Review 2, 33-42.

Hicap, Jonathan M. 2007. How CEP will serve entire archipelago's school system.” http://www.manilatimes.net/national/2007/aug/19/yehey/top_stories/20070819top2.html

Hill, Maggie and Joan Novelli, 1994. Multimedia in the classroom - benefits to teachers and students - includes related articles - Special Section

Jackson, Paul. 2002. Advantages in Using Multimedia in the Classroom. British Council, Lisbon

Kern 1995. The ideal multimedia-enabled classroom: perspectives from psychology, education, and information science.Journal of Educational Multimedia and Hypermedia.

Mathis and Clark 1993. Mathis, G., \& Clarke, P. (1993, Spring). Creating a multimedia classroom. ACM SIGUCCS Newsletter, 23(1), 6-9.

Muller et al. 2008

National Science Foundation (1996). Information technology: Its impact on undergraduate education in science, mathematics, engineering and technology, NSF (pp. 98-82).

Oblinger, D. 1991. Introduction to multimedia in instruction--Maximizing multimedia: A how-to-session for faculty. Unpublished manuscript distributed during training, Dallas County Community College District at Dallas, (Courtesy of PBS Adult Learning Satellite Service).

Shelly, Waggoner, Cashman\& Waggoner, 1998

Singhal, 1997 
Slack, Roger.1999. The use of multimedia in schools. Center for Educational Sociology. 'Learning in Cable School', document prepared for EC TSER Social Learning in Multimedia project.

Todd, B. A. (1997). Cooperative learning in a distance-learning environment. 1997 ASEE Southeastern Section Meeting, Marietta, GA.

Warschauer et al., 1996

Wiburg et. al., 2002

http://www.deped.gov.ph, 2007

Wiburg, K. M., and Buler-Pascoe. 2002. Bridging Pedadogy and Technology. Australasian Journal of Educational Technology. 2006, 22(3), 375-397

Young, Jan. 2007. Making a Difference. Raven Publishing. Western International.ISBN: 978-0-9772525-5-8

http://www.deped.gov.ph, 2007 